\title{
DISTINCTIVE SITE PREFERENCE OF THE FISH PARASITE MYXOBOLUS CEREBRALIS (CNIDARIA, MYXOZOA) DURING HOST INVASION
}

\author{
Edit EszTERBAuer ${ }^{*}$, Dóra SiPos, Ágnes SzAKÁly and Dávid HERCZEG ${ }^{\#}$ \\ Institute for Veterinary Medical Research, Centre for Agricultural Research, \\ Hungarian Academy of Sciences, Hungária krt. 21, H-1143 Budapest, Hungary; \\ "Present address: Plant Protection Institute, Centre for Agricultural Research, \\ Hungarian Academy of Sciences, Budapest, Hungary
}

(Received 18 January 2019; accepted 2 May 2019)

\begin{abstract}
Here, we experimentally studied the site preference of Myxobolus cerebralis, one of the most pathogenic myxozoan (Cnidaria, Myxozoa) fish parasites, which causes whirling disease in salmonids. Parasite invasion was examined in three fish species with various susceptibility levels: the type host brown trout, the highly susceptible rainbow trout, and the non-susceptible gibel carp, in which parasite spores do not develop. We investigated the first two hours of fish invasion, and measured the site preference of triactinomyxons (TAMs) during attachment and penetration of fish in three body parts (gills, fins, skin). Infection prevalence and intensity were estimated using a species-specific nested PCR, optimised in the present study. The highest infection prevalence was detected in the most susceptible fish species, rainbow trout. Interestingly, higher prevalence was observed in gibel carp than in the type host, brown trout ( $95.2 \%$ vs. $85.7 \%)$. Considering body locations, remarkable differences were detected in infection intensities. The highest intensity was observed in fins, whereas skin was the least infected body part in every fish species examined. Infection prevalence and intensity did not differ significantly among fish species. Thus, we confirmed that $M$. cerebralis TAMs cannot discern fish species. Furthermore, we proved experimentally that fish fin is significantly more attractive to fish-invading parasite TAMs than gills or skin.
\end{abstract}

Key words: Myxozoans, TAM, host-parasite interaction, gibel carp, rainbow trout, brown trout, whirling disease

Myxozoa represents a diverse group of microscopic-size endoparasites belonging to phylum Cnidaria (Jiménez-Guri et al., 2007; Fiala et al., 2015; Atkinson et al., 2018). Myxobolus cerebralis Höfer, 1903 is one of the most pathogenic members of the taxon, responsible for high mortality among salmonids by causing whirling disease (O'Grodnick, 1979; Hoffman, 1990). The complex, twohost life cycle of the parasite includes the definitive host oligochaete Tubifex tu-

*Corresponding author; E-mail: eszterbauer.edit@agrar.mta.hu 
bifex (Annelida: Clitellata) invaded by the parasites' myxospore stage, and salmonid fishes (intermediate hosts) that are infected by the actinospore stage of the parasite (Markiw and Wolf, 1983). The triactinomyxon-type actinospores (triactinomyxons, TAMs) are a water-borne form of Myxobolus cerebralis that leave the oligochaete host along with faeces, and float in the water column waiting for an encounter with the fish host.

Myxobolus cerebralis has a relatively wide host range. The parasite primarily infects salmonids, and causes severe disease in rainbow trout Oncorhynchus mykiss, cutthroat trout $O$. clarki, Yellowstone cutthroat trout $O$. c. bouvieri, sockeye salmon $O$. nerka and Danube salmon Hucho hucho (Steinbach Elwell et al., 2009). Mild infection is described in brown trout Salmo trutta m. fario, whereas closely related salmonid species may show different levels of clinical signs (Höfer, 1903; Hoffman and Putz, 1969; El-Matbouli et al., 1992; Hedrick et al., 2001; MacConnell and Vincent, 2002). There are also differences in susceptibility, prevalence, infection intensity and mortality among salmonid species or even strains (Steinbach Elwell et al., 2009). Brown trout, which are native to Europe, are the original host of the parasite, and as a result of the shared evolutionary origin of the parasite and host, brown trout developed an effective immune strategy against $M$. cerebralis (Hoffman, 1970). Whirling disease was not observed in Europe before the introduction of the highly susceptible, non-native rainbow trout from North America (Hedrick et al., 1999; Bartholomew and Reno, 2002). It is known from previous studies that host recognition of $M$. cerebralis is not a fish species-specific reaction (Kallert et al., 2009, 2015). Although cyprinid fishes are not susceptible to M. cerebralis, fish-invasive TAMs are capable of penetrating their skin, but mature spores of M. cerebralis do not develop (El-Matbouli et al., 1999; Kallert et al., 2009; Sipos et al., 2018).

During host invasion, TAMs attach to the skin of fish and the parasite sporoplasm, which contains the infective germ cells (sporozoites), leaves the TAM with active movement and penetrates the skin of fish through the mucous layer. Fish mucus represents a first barrier against parasites from the environment; however, it plays a significant role in the host recognition process as well. Initially, TAMs require a fish mucus-derived chemical and a mechanical (i.e. active movement of fish) stimulus for host recognition (Kallert et al., 2005, 2011). Early studies suggested that TAMs mainly target the epithelium of buccal cavity, fins, gills, and skin of the host during penetration (El-Matbouli et al., 1992; Yokoyama and Urawa, 1997; Antonio et al., 1999). While available information about the site preference of $M$. cerebralis TAMs to different body parts of fish is rather scarce, it is known that there is no significant difference in the number of actively emerging $M$. cerebralis sporoplasms in the skin of highly and less susceptible strains of rainbow trout and the non-susceptible host common carp, Cyprinus carpio (Kallert et al., 2009; Steinbach Elwell et al., 2009). 
In the present study, we experimentally studied the early stage of $M$. cerebralis invasion in three fish species with various susceptibility levels (i.e. the original host, brown trout, the highly susceptible rainbow trout and a nonsusceptible cyprinid species, gibel carp, Carassius gibelio). We used in vivo laboratory experiments, and estimated parasite intensity in fish using a semiquantitative PCR assay, to explore if there was a difference in the site preference of the parasite among the fish species.

\section{Materials and methods}

\section{Source and maintenance of parasite and fish hosts}

The M. cerebralis used for experimental exposure originated from the life cycle maintained in the laboratory of the Institute for Veterinary Medical Research, Budapest, Hungary since 2007, as described by Eszterbauer et al. (2015). The parasite spores were regularly checked by microscopy and DNA sequencing for contamination by other myxozoans (which were never detected). Rainbow trout (Kamloops strain) and brown trout were obtained from the Lillafüred Trout Hatchery at Lillafüred, Hungary. Trout fry were kept in a parasite-free environment in the hatchery, and transported to the laboratory about a week after hatching, in 'yolk-sac stage'. Prior to exposure, fish were kept in aerated, water flowthrough aquaria at $15^{\circ} \mathrm{C}$. The fertilised eggs of gibel carp were sourced from a cyprinid fish farm at Hortobágy, Hungary, and they were transported to the laboratory before hatching. Fish were reared under parasite-free laboratory conditions in aerated aquaria at $15{ }^{\circ} \mathrm{C}$ for salmonids and at $20 \pm 2{ }^{\circ} \mathrm{C}$ for gibel carp. All fish species were fed with commercial fish pellets (Aller Aqua, Denmark) $a d$ libitum. For the experimental exposure, 7-8 weeks old brown and rainbow trout (7-7.5 $\mathrm{cm}$ long), and 1-year-old gibel carp specimens (5.5-7 $\mathrm{cm}$ long) were used.

\section{Experimental exposure}

Parasite TAMs were harvested by filtering the water from the culture containers through a $20-\mu \mathrm{m}$ nylon mesh as described previously (Forró and Eszterbauer, 2016). TAMs used for the infection trials were $<2$ days old. Naïve fish were exposed individually to 10,000 freshly filtered TAMs/fish in $500 \mathrm{ml}$ dechlorinated tap water for $2 \mathrm{~h}$ at $15{ }^{\circ} \mathrm{C}$. Twenty-one fish of each species were exposed, and the same number of non-exposed control fish were kept under identical conditions without the addition of TAMs. Samples were taken $2 \mathrm{~h}$ post exposure (p.e.). During sample collection, fish were first anaesthetised with $200 \mathrm{mg} / \mathrm{l}$ tricaine methanesulphonate (MS222, Sigma, Germany), and killed by cranial cut, per a protocol approved by the National Scientific Ethical Committee on Animal Experimentation (Hungary), which provided full approval for the animal experi- 
ment (No. XIV-I-001/1326-4/2012 and PEI/001/4087-4/2015). From every fish, two whole gill arches and approximately $1 \mathrm{~cm}^{2}$ of skin (without muscle tissue) and $1 \mathrm{~cm}^{2}$ of caudal fin were sampled. The weight of samples was measured and recorded. The mean weight of sampled gills, skin and fin was $69.10 \pm 12.57$, $50.54 \pm 13.05$ and $67.83 \pm 15.98$, respectively (mean weight \pm SD). The samples were stored at $-20{ }^{\circ} \mathrm{C}$ until further molecular use.

\section{Isolation of DNA and nested PCR analysis}

Skin, gill and fin samples of all examined fish species were homogenised manually with a polypropylene micropestle (ThermoFisher Scientific, USA) in a 1.5-ml microcentrifuge tube. DNA was extracted using a DNeasy Blood \& Tissue Kit (Qiagen, Germany) according to the manufacturer's instructions. The amount and integrity of extracted genomic DNA were checked with $1 \%$ agarose gel electrophoresis in $0.5 \times$ TAE buffer, and with a NanoDrop 2000c spectrophotometer (ThermoFisher Scientific, USA).

An M. cerebralis-specific nested PCR assay was used to amplify a fragment of the parasite's 18S rDNA. The primer combination was chosen and optimised in the present study. The nested PCR profile comprised an initial denaturation at $94{ }^{\circ} \mathrm{C}$ for $10 \mathrm{~min}$, followed by 35 cycles of denaturation $\left(30 \mathrm{~s}\right.$ at $\left.94{ }^{\circ} \mathrm{C}\right)$, annealing $\left(30 \mathrm{~s}\right.$ at $\left.56^{\circ} \mathrm{C}\right)$, and elongation $\left(50 \mathrm{~s}\right.$ at $\left.72{ }^{\circ} \mathrm{C}\right)$, then a final elongation step at $72{ }^{\circ} \mathrm{C}$ for $5 \mathrm{~min}$. The total volume of PCR mixture was $25 \mu \mathrm{l}$, which contained $1 \times$ Taq buffer with $\mathrm{KCl}$ (ThermoFisher Scientific, USA), $0.25 \mu \mathrm{M}$ of both forward and reverse primers (IDT, Belgium), $0.2 \mu \mathrm{M}$ dNTPs (Sigma, Germany), $1.5 \mathrm{mM} \mathrm{MgCl}_{2}$ (Thermo Scientific, USA), $1.25 \mathrm{U}$ recombinant Taq DNA polymerase (ThermoFisher Scientific, USA), nuclease-free water, and approximately 50 ng template DNA (all DNA samples were diluted to the same concentration prior to PCR). In the first round of the nested PCR, primers were Tr5-17 (5'GCC CTA TTA ACT AGT TGG TAG TAT AGA AGC-3'; Andree et al., 1998) and Myx18-996R (5'-GCG GTC TGG GCA AAT GC-3'; Kelley et al., 2004). In the second round, primers Tr3-17 (5'-GGC ACA CTA CTC CAA CAC TGA ATT TG-3'; Andree et al., 1998) and Myx18-909f-R (5'-TGC TGT AAC TGA ATA ACA TTC AGT CAA AG-3', reverse complement of the one designed by Kelley et al., 2004) were used. Amplicon size was 783 bp and 245 bp, respectively. PCR products were visualised on $2.0 \%$ agarose gels in $0.5 \times \mathrm{TAE}$ buffer.

Semi-quantification of parasite amount was based on fluorescence intensity of parasite PCR amplicon compared with a known amount of DNA ladder (GeneRuler 100 bp Plus DNA ladder, ThermoFisher Scientific, USA). We scored samples as one of four categories: $(-)$ no visible product either in the first- or in the second-round PCR; $(+)$ no visible product in the first round, second round weak positive; $(++)$ first round weak positive, second round strong positive, and $(+++)$ strong positivity in both rounds. 


\section{Statistical analysis}

The prevalence and intensity of infection were calculated from molecular data, and the obtained values were statistically analysed with R (version 3.4.4; R Core Team, 2018). Fisher's exact test was used to analyse differences in parasite occurrence in different body locations. The Kruskal-Wallis H test was applied to compare differences in infection intensity among host species. If a significant difference was detected, pairwise comparisons were implemented with the Mann-Whitney U test. For different body locations (i.e. skin, gill, and fin), the Friedman test was used, and the Mann-Whitney $U$ test applied for pairwise comparisons. The $\mathrm{P}$ values were corrected by the Bonferroni-Holm method. The level of significance was determined at $\mathrm{P}<0.05$, and marginal significance was identified in cases when the $\mathrm{P}$ value was between 0.05 and 0.1 .

\section{Results}

The prevalence of $M$. cerebralis infection was between $85.7-100 \%$, which confirmed the high efficiency of the experimental infection regime. The highest prevalence was detected in the most susceptible fish species, rainbow trout. Interestingly, gibel carp had $95.2 \%$ prevalence, a higher value than in the type host, brown trout $(85.7 \%)$ (Table 1$)$. The occurrence of parasite was significantly different among body locations for every fish species; highest occurrence was found in fins, and lowest in skin (Table 1, Fig. 1). We found no significant difference between fish species; however, occurrence in skin was borderline significant $(\mathrm{P}=0.059)$, with the lowest parasite occurrence in brown trout. Control fish were all PCR negative.

The infection intensity varied slightly among fish species (Fig. 2), and the intensity differences among species correlated with the trend of prevalence (regarding fish species). The highest intensity was detected in rainbow trout, and the lowest in brown tout (Fig. 1 sum). Most of these relations were, however, not significantly different. Using pairwise comparison, we found significant disparity in one case, in the infection intensity in fin samples between brown trout and rainbow trout $(\mathrm{P}=0.002)$. Furthermore, marginal significance was observed between the skin samples of brown trout and rainbow trout $(\mathrm{P}=0.059)$ and between the fin samples of gibel carp and rainbow trout $(\mathrm{P}=0.061)$ (Table 2). Considering body locations, significant differences in infection intensities were detected in most cases (Table 3). The highest intensity was detected in fins, while skin was the least infected body part in every fish species examined (Fig. 1). Gill infection showed average intensity among the three examined body parts (Fig. 2 sum). Infection intensity in fin was significantly higher than that in skin, for every fish species. Fin infection was significantly higher than that of the gills in 
rainbow trout and gibel carp, whereas gill was significantly more intensively infected than skin in brown trout (Table 3).

\section{Table 1}

Prevalence, parasite occurrence and intensity parameters of the early stage of Myxobolus cerebralis infection among the examined fish species $2 \mathrm{~h}$ post exposure. Intensity categories: $(+)$ first round of nested PCR negative, second round weak positive; $(++)$ first round weak positive, second round strong positive, and $(+++)$ strong positivity in both rounds

\begin{tabular}{|c|c|c|c|c|c|c|c|}
\hline \multirow{2}{*}{$\begin{array}{l}\text { Fish } \\
\text { species }\end{array}$} & \multirow{2}{*}{$\begin{array}{l}\text { Body } \\
\text { location }\end{array}$} & \multirow{2}{*}{$\begin{array}{l}\text { No. of } \\
\text { infected/ } \\
\text { exposed } \\
\text { fish }\end{array}$} & \multirow{2}{*}{$\begin{array}{l}\text { Prevalence } \\
(\%)\end{array}$} & \multirow{2}{*}{$\begin{array}{l}\text { Occurrence } \\
\text { per } \\
\text { body part } \\
(\%)\end{array}$} & \multicolumn{3}{|c|}{$\begin{array}{c}\text { Infection intensity per category } \\
(\%)\end{array}$} \\
\hline & & & & & + & ++ & +++ \\
\hline \multirow{3}{*}{ Brown trout } & fin & \multirow{3}{*}{$18 / 21$} & \multirow{3}{*}{85.7} & 76.2 & 37.5 & 56.3 & 6.3 \\
\hline & gill & & & 61.9 & 23.1 & 69.2 & 7.7 \\
\hline & skin & & & 14.3 & 33.3 & 66.7 & 0.0 \\
\hline \multirow{3}{*}{ Rainbow trout } & fin & \multirow{3}{*}{$21 / 21$} & \multirow{3}{*}{100} & 95.0 & 5.3 & 52.6 & 42.1 \\
\hline & gill & & & 61.9 & 61.5 & 38.5 & 0.0 \\
\hline & skin & & & 47.6 & 20.0 & 80.0 & 0.0 \\
\hline \multirow{3}{*}{ Gibel carp } & fin & \multirow{3}{*}{$20 / 21$} & \multirow{3}{*}{95.2} & 90.5 & 26.3 & 57.9 & 15.8 \\
\hline & gill & & & 52.4 & 63.6 & 36.4 & 0.0 \\
\hline & skin & & & 38.1 & 62.5 & 37.5 & 0.0 \\
\hline \multirow{3}{*}{ All fish } & fin & \multirow{3}{*}{$59 / 63$} & \multirow{3}{*}{93.6} & 87.1 & 22.2 & 55.6 & 22.2 \\
\hline & gill & & & 58.7 & 48.6 & 48.6 & 2.7 \\
\hline & skin & & & 30.2 & 38.1 & 61.9 & 0.0 \\
\hline
\end{tabular}

\section{Discussion}

The severity of whirling disease in salmonids depends on the age and size of fish when first exposed to M. cerebralis (Steinbach Elwell et al., 2009). The susceptibility of salmonids declines considerably after the age of 9 weeks (Ryce et al., 2004). Water temperature and infection dose are also important factors (O'Grodnick, 1979; Ryce et al., 2004; Steinbach Elwell et al., 2009). The viability of TAMs is strongly water temperature dependent, and above $20^{\circ} \mathrm{C}$, there is a remarkable drop in the viability and infectivity of TAMs (Steinbach Elwell et al., 2009; Kallert et al., 2015). Therefore all of these factors were considered in the experimental setup.

In the present study, we investigated the first two hours of fish invasion, i.e. the early phase of $M$. cerebralis infection, and measured the site preference of TAMs during attachment and penetration. Up to $100 \%$ infection prevalence was observed in the experimental exposure, which was likely due to the optimised exposure protocol developed in the Fish Parasitology Laboratory of the 
Institute for Veterinary Medical Research, Hungary (Eszterbauer et al., 2009, 2015; Forró and Eszterbauer, 2016; Sipos et al., 2018), and the relatively high dose of parasite used for fish exposure compared to natural systems, where the prevalence of myxozoan infection is usually lower (Beauchamp et al., 2002; DuBey and Caldwell, 2004; Hallett et al., 2012). Hedrick et al. (1999) examined the susceptibility of brown trout and rainbow trout to whirling disease in a dosedependent context, by exposing age-matched groups of different trout species in parallel with 10, 100, 1,000 and 10,000 TAMs per fish for 2 hours. In our study, we used a high dose of parasite (i.e. 10,000 TAMs per fish) to be able to examine the earliest stage of parasite development in fish, where microscopic detection cannot be used for evaluation. In this case, the only sufficient method is DNAbased molecular detection that requires a higher dose of exposure for proper comparison of samples (Sipos et al., 2018).
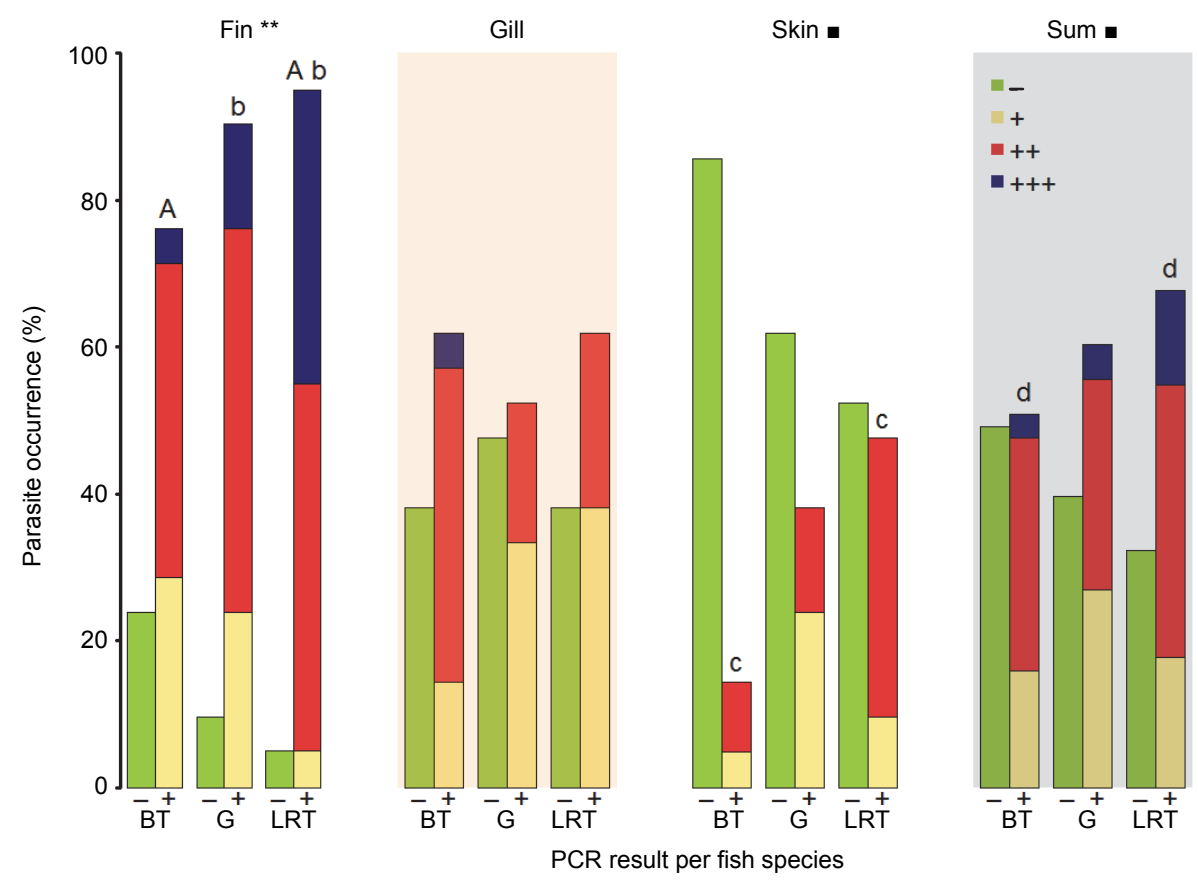

Fig. 1. Comparison of Myxobolus cerebralis infection intensity among fish species examined. Semi-quantification of infection intensity amount was performed on the basis of the intensity of parasite-specific PCR product. The following four categories were determined: (-/green) negative; (+/yellow) first round negative, second round weak positive; $(++/$ red) first round weak positive, second round strong positive, and $(+++$ /blue $)$ strong positivity in both rounds. BT = brown trout; $\mathrm{G}=$ gibel carp; LRT $=$ rainbow trout. Level of significance with Kruskal-Wallis test: ${ }^{*}$ corrected $\mathrm{P}$ value between $0.05-0.01 ;{ }^{* *} 0.01-0.001 ;{ }^{* * *}<0.001$. Marginal significance: - P value between $0.1-$ 0.05 . Significant differences between species (obtained with pairwise comparison) are indicated with upper-case letters, marginally significant differences are indicated with lower-case letters 

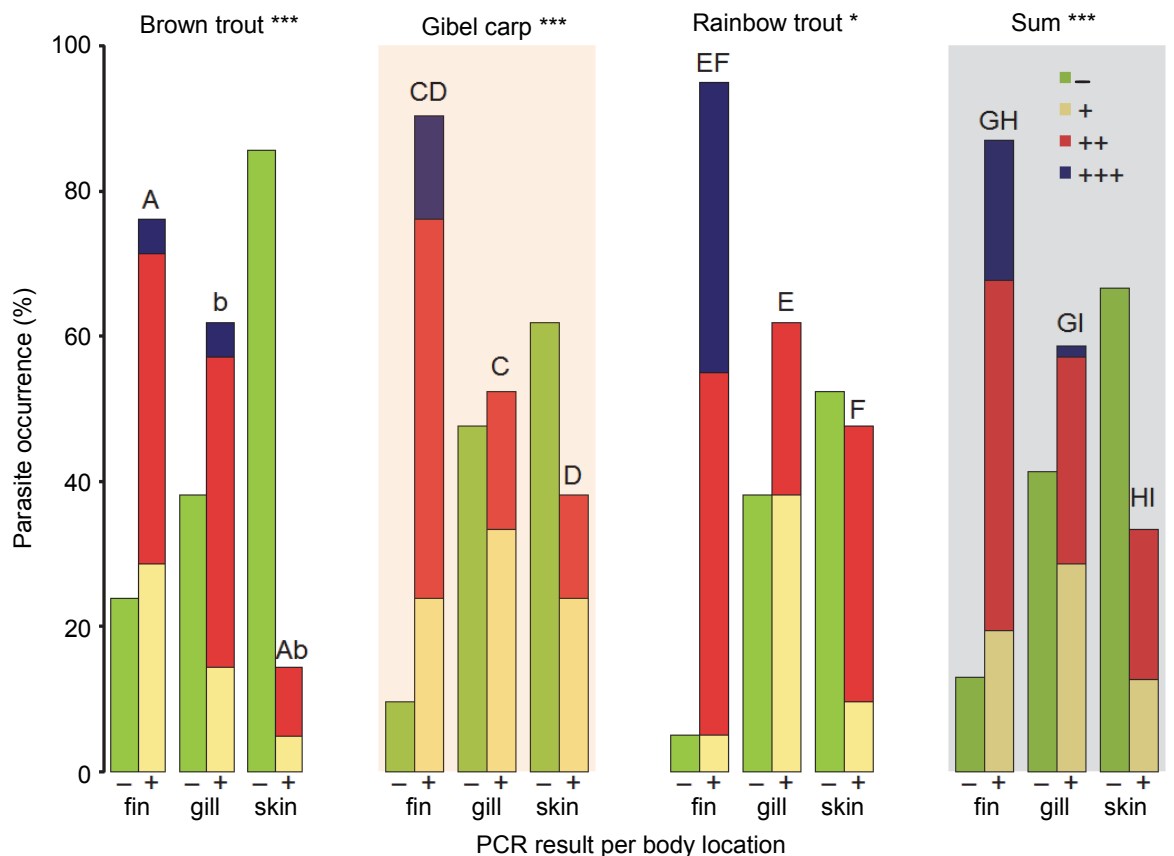

Fig. 2. Comparison of Myxobolus cerebralis infection intensity among body locations examined. Semi-quantification of M. cerebralis infection intensity amount was performed on the basis of the intensity of parasite-specific PCR product. The following four categories were determined:

(-/green) negative; (+/yellow) first round negative, second round weak positive; $(++/$ red $)$ first round weak positive, second round strong positive, and $(+++/$ blue $)$ strong positivity in both rounds.

Level of significance with Friedman test: ${ }^{*}$ corrected P value between $0.05-0.01 ;{ }^{* *} 0.01-0.001$;

${ }^{* * *}<0.001$. Marginal significance: $-\mathrm{P}$ value between $0.1-0.05$. Significant differences between body locations (obtained with pairwise comparison) are indicated with upper-case letters, marginally significant differences are indicated with lower-case letters

Table 2

Corrected P values of pairwise comparison of Myxobolus cerebralis infection intensity among fish species obtained with Mann-Whitney U test. Significant difference is highlighted in bold. Marginal significance is labelled in italics

\begin{tabular}{lccc}
\hline & Brown trout - Gibel carp & Brown trout - Rainbow trout & Gibel carp - Rainbow trout \\
\hline Fin & 0.130 & $\mathbf{0 . 0 0 2}$ & 0.061 \\
Gill & 0.500 & 0.715 & 0.715 \\
Skin & 0.226 & 0.059 & 0.288 \\
\hline Sum (all sites) & 0.536 & 0.081 & 0.173 \\
\hline
\end{tabular}

Quantitative real-time PCR (qPCR) methods have become a valuable tool to estimate infection and parasite load of M. cerebralis (Cavender et al., 2004, Kelley et al., 2004; Sipos et al., 2018). Nonetheless, we applied an M. cerebralis- 
specific nested PCR assay to amplify a fragment of the $18 \mathrm{~S}$ rDNA instead of using qPCR, based on pilot comparisons. We tested both detection methods (i.e. the species-specific qPCR by Sipos et al., 2018, and the nested PCR assay developed in the present study), and we found that the nested PCR had similar sensitivity of parasite detection compared to qPCR (supplementary data are available from the corresponding author upon request). Importantly, PCR had an advantage over qPCR as it did not require normalisation using reference genes (i.e. internal controls), which are different between the three fish hosts, thus qPCR normalisation is not equally sensitive to salmonids and cyprinids, therefore the relative quantification using qPCR would have distorted data. In order to compare parasite DNA amounts in different organs from various fish species, sample normalisation was done in two steps. First, similar-sized tissue samples were collected, then an equal amount of extracted DNA was used for the nested PCR. Therefore, nested PCR was an appropriate method for a semi-quantitative comparison of M. cerebralis invasion in salmonid and cyprinid hosts.

Table 3

Corrected $\mathrm{P}$ values of pairwise comparison of Myxobolus cerebralis infection intensity among body parts of fish obtained with Mann-Whitney U test. Significant difference is highlighted in bold

\begin{tabular}{lccc}
\hline & Fin - Gill & Fin - Skin & Fin - Skin \\
\hline Brown trout & 0.656 & $\mathbf{0 . 0 0 2}$ & $\mathbf{0 . 0 1 8}$ \\
Rainbow trout & $\mathbf{0 . 0 0 1}$ & $\mathbf{0 . 0 0 2}$ & 0.935 \\
Gibel carp & $\mathbf{0 . 0 0 6}$ & $\mathbf{0 . 0 0 1}$ & 0.463 \\
\hline Sum (all fish) & $<\mathbf{0 . 0 0 1}$ & $<\mathbf{0 . 0 0 1}$ & $\mathbf{0 . 0 3 1}$
\end{tabular}

Kallert et al. (2009) examined the penetration of M. cerebralis TAMs into susceptible (rainbow trout) and non-susceptible (common carp) species. They proved that there is no significant difference in the amount of penetrating M. cerebralis sporozoites between the highly susceptible rainbow trout strains and the non-susceptible common carp. Their study focused on the first three minutes of host invasion (as fish were exposed to M. cerebralis for $3 \mathrm{~min}$, then samples were taken immediately). In our study, the aim was to examine the putative difference in case of a prolonged parasite exposure (up to $2 \mathrm{~h}$ ), when the activity of fish does not count, and the parasite may have time to reach all body parts of fish. Kallert et al. (2009) found that the gills of common carp were more infected (i.e. higher number of parasite stages were detected) than those of rainbow trout, but the difference was not significant. Although gibel carp in our study had almost the same age as common carp in the experiment by Kallert et al. (2009) (12 months vs. 11 months old), we found the opposite relation in gibel carp, a close relative of common carp. However, the difference observed by us was not signif- 
icant either. On the other hand, we found that fin was a significantly more attractive target to fish-invading TAMs than skin or gill. Interestingly, skin was the least-attacked body location, although previous studies based on histology found that skin is the most favoured target of entry by the parasite (El-Matbouli et al., 1995). Kallert et al. (2009) also compared different body parts and found that gill was the most attractive organ, followed by fins, with fewest TAMs were detected in the mucous layer of skin. Here, we studied the host invasion $2 \mathrm{~h}$ p.e. (i.e. up to $2 \mathrm{~h}$ after penetration), and we detected a significantly higher amount of parasite in fins than in skin or even gills. This might be due to the timing of infection, and the physiological differences among the examined body parts. Fish fins, especially the caudal fin, are usually in motion, and thereby they create more intensive mechanical stimuli for the parasite, with a higher chance to get into contact with water-floating TAMs. The constant water flow across in the gills also produces a strong mechanical stimulus that makes them an attractive target for TAMs. By these criteria, skin, including the mucous outer layer of fish, however, has less active movement, and it has a relative large surface compared to fins or gills (thereby the relative number of parasites per unit area is likely lower). During host invasion, it is likely that in the first few minutes of infection, body parts able to 'produce' more intensive mechanical stimuli (i.e. gills and fins), and those able to contact the parasite more easily and in higher number are preferred. For extended exposure (i.e. $2 \mathrm{~h}$ in our study vs. $3 \mathrm{~min}$ for Kallert et al., 2009), there may be more time for the parasite to reach 'less active' body parts as well and equilibrate the dose across multiple surfaces.

In the present study, we confirmed the findings of previous studies (e.g., Kallert et al., 2009; Sipos et al., 2018) that M. cerebralis TAMs cannot discern fish species and strains, as infection prevalence and intensity did not differ significantly among the examined fish species, no matter how susceptible they were to the parasite. However, we showed that fish fin is significantly more attractive to fishinvading parasite TAMs than gills or skin. We found evidence for the site selection of TAM sporozoites, which is thereby the first experimental proof for the distinctive site preference of $M$. cerebralis.

\section{Acknowledgements}

The study was funded by the National Research, Development and Innovation Office (grant no.: NN124220). We thank one of the anonymous reviewers for the careful reading of our manuscript, and the insightful comments and suggestions.

\section{References}

Andree, K. B., MacConnell, E. and Hedrick, R. P. (1998): A nested polymerase chain reaction for the detection of genomic DNA of Myxobolus cerebralis in rainbow trout (Oncorhynchus mykiss). Dis. Aquat. Org. 34, 145-154. 
Antonio, D. B., El-Matbouli, M. and Hedrick, R. P. (1999): Detection of early developmental stages of Myxobolus cerebralis in fish and tubificid oligochaete hosts by in situ hybridization. Parasitol. Res. 85, 942-944.

Atkinson, S. D., Bartholomew, J. L. and Lotan, T. (2018): Myxozoans: Ancient metazoan parasites find a home in phylum Cnidaria. Zoology 129, 66-68.

Bartholomew, J. L. and Reno, P. W. (2002): The history and dissemination of whirling disease. In: Bartholomew, J. L. and Wilson, J. C. (eds): Whirling Disease: Reviews and Current Topics. American Fisheries Society, Symposium 29, Bethesda, Maryland, USA. pp. 3-24.

Beauchamp, K. A., Gay, M., Kelley, G. O., El-Matbouli, M., Kathman, R. D., Nehring, R. B. and Hedrick, R. P. (2002): Prevalence and susceptibility of infection to Myxobolus cerebralis, and genetic differences among populations of Tubifex tubifex. Dis. Aquat. Org. 51, 113-121.

Cavender, W. P., Wood, J. S., Powell, M. S., Overturf, K. and Cain, K. D. (2004): Real-time quantitative polymerase chain reaction (qPCR) to identify Myxobolus cerebralis in rainbow trout Oncorhynchus mykiss. Dis. Aquat. Org. 60, 205-213.

DuBey, R. and Caldwell, C. (2004): Distribution of Tubifex tubifex lineages and Myxobolus cerebralis infection in the tailwater of the San Juan River, New Mexico. J. Aquat. Anim. Health 16, 179-185.

El-Matbouli, M., Fischer-Scherl, T. and Hoffmann, R. W. (1992): Present knowledge on the life cycle, taxonomy, pathology and therapy of some Myxosporea spp. important for freshwater fish. Annu. Rev. Fish Dis. 3, 367-402.

El-Matbouli, M., Hoffmann, R. W. and Mandok, C. (1995): Light and electron microscopic observations on the route of the triactinomyxon-sporoplasm of Myxobolus cerebralis from epidermis into rainbow trout cartilage. J. Fish Biol. 46, 919-935.

El-Matbouli, M., Hoffmann, R. W., Schoel, H., McDowell, T. S. and Hedrick, R. P. (1999): Whirling disease: host specificity and interaction between the actinosporean stage of Myxobolus cerebralis and rainbow trout Oncorhynchus mykiss. Dis. Aquat. Org. 35, 1-12.

Eszterbauer, E., Atkinson, S. D., Diamant, A., Morris, D., El-Matbouli, M. and Hartikainen, H. (2015): Myxozoan Life Cycles: Practical Approaches and Insights. In: Okamura, B., Gruhl, A. and Bartholomew, J. L. (eds) Myxozoan Evolution, Ecology and Development. Springer International Publishing, Switzerland. pp. 175-198.

Eszterbauer, E., Kallert, D. M., Grabner, D. and El-Matbouli, M. (2009): Differentially expressed parasite genes involved in host recognition and invasion of the triactinomyxon stage of Myxobolus cerebralis (Myxozoa). Parasitology 136, 367-377.

Fiala, I., Bartošová-Sojková, P. and Whipps, C. M. (2015): Classification and phylogenetics of Myxozoa. In: Okamura, B., Gruhl, A. and Bartholomew, J. L. (eds) Myxozoan Evolution, Ecology and Development. Springer International Publishing, Switzerland. pp. 85-110.

Forró, B. and Eszterbauer, E. (2016): Correlation between host specificity and genetic diversity for the muscle-dwelling fish parasite Myxobolus pseudodispar: examples of myxozoan hostshift? Folia Parasitol. (Praha) 63, 019.

Hallett, S. L., Ray, R. A., Hurst, C. N., Holt, R. A., Buckles, G. R., Atkinson, S. D. and Bartholomew, J. L. (2012): Density of the waterborne parasite Ceratomyxa shasta and its biological effects on salmon. Appl. Environ. Microbiol. 78, 3724-3731.

Hedrick, R. P., McDowell, T. S., Guy, M., Marty, G. D., Georgiadis, M. P. and MacConnell, E. (1999): Comparative susceptibility of rainbow trout Oncorhynchus mykiss and brown trout Salmo trutta to Myxobolus cerebralis, the cause of salmonid whirling disease. Dis. Aquat. Org. 37, 173-183.

Hedrick, R. P., McDowell, T. S., Mukkatira, K., Georgiadis, M. P. and MacConnell, E. (2001): Susceptibility of three species of anadromous salmonids to experimentally induced infectious with Myxobolus cerebralis, the causative agent of whirling disease. J. Aquat. Anim. Health 13, 43-50.

Höfer, B. (1903): Über die Drehkrankheit der Regenbogenforelle [in German]. Allgemeine Fischerei Zeitung 28, 7-8. 
Hoffman, G. L. (1970): Intercontinental and transcontinental dissemination and transfaunation of fish parasites with emphasis on whirling disease. In: Snieszko, S. F. (ed.) Symposium on Diseases of Fishes and Shellfishes. American Fisheries Society. pp. 69-81.

Hoffman, G. L. (1990): Myxobolus cerebralis, a worldwide cause of salmonid whirling disease. J. Aquat. Anim. Health 2, 30-37.

Hoffman, G. L. and Putz, R. E. (1969): Host susceptibility and the effect of ageing, freezing, heat, and chemicals on the spores of Myxosoma cerebralis. Prog. Fish-Cult. 31, 35-37.

Jiménez-Guri, E., Philippe, H., Okamura, B. and Holland, P. H. W. (2007): Buddenbrockia is a cnidaria worm. Science 317, 116-118.

Kallert, D. M., Bauer, W., Haas, W. and El-Matbouli, M. (2011): No shot in the dark: Myxozoans chemically detect fresh fish. Int. J. Parasitol. 41, 271-276.

Kallert, D. M., El-Matbouli, M. and Haas, W. (2005): Polar filament discharge of Myxobolus cerebralis actinospores is triggered by combined non-specific mechanical and chemical cues. Parasitology 131, 609-616.

Kallert, D. M., Eszterbauer, E., Grabner, D. and El-Matbouli, M. (2009): In vivo exposure of susceptible and non-susceptible fish species to Myxobolus cerebralis actinospores reveals nonspecific invasion behaviour. Dis. Aquat. Org. 84, 123-130.

Kallert, D. M., Grabner, D. S., Yokoyama, H., El-Matbouli, M. and Eszterbauer, E. (2015): Transmission of Myxozoans to Vertebrate Hosts. In: Okamura, B., Gruhl, A. and Bartholomew, J. L. (eds) Myxozoan Evolution, Ecology and Development. Springer International Publishing, Switzerland. pp. 235-251.

Kelley, G. O., Zagmutt-Vergara, F. J., Leutenegger, C. M., Myklebust, K. A., Adkison, M. A., McDowell, T. S., Marty, G. D., Kahler, A. L., Bush, A. L., Gardner, I. A. and Hedrick, R. P. (2004): Evaluation of five diagnostic methods for the detection and quantification of Myxobolus cerebralis. J. Vet. Diagn. Invest. 16, 202-211.

MacConnell, E. and Vincent, E. R. (2002): Review: The effects of Myxobolus cerebralis on the salmonid host. In: Bartholomew, J. L. and Wilson, J. C. (eds) Whirling Disease: Reviews and Current Topics. American Fisheries Society, Symposium 29, Bethesda, Maryland, USA. pp. 95-107.

Markiw, M. E. and Wolf, K. (1983): Myxosoma cerebralis (Myxozoa: Myxosporea) etiologic agent of salmonid whirling disease requires tubificid worm (Annelida: Oligochaeta) in its life cycle. J. Protozool. 30, 561-564.

O'Grodnick, J. J. (1979): Susceptibility of various salmonids to whirling disease (Mxyosoma cerebralis). Trans. Am. Fish Soc. 108, 187-190.

R Core Team (2018): R: A language and environment for statistical computing. R Foundation for Statistical Computing, Vienna, Austria. http://www.R-project.org/.

Ryce, E. K., Zale, A. V. and MacConnell, E. (2004): Effects of fish age and parasite dose on the development of whirling disease in rainbow trout. Dis. Aquat. Org. 59, 225-233.

Sipos, D., Ursu, K., Dán, Á., Herczeg, D. and Eszterbauer, E. (2018): Susceptibility-related differences in the quantity of developmental stages of Myxobolus spp. (Myxozoa) in fish blood. PLoS ONE 13, e0204437.

Steinbach Elwell, L. C., Stromberg, K. E., Ryce, E. K. N. and Bartholomew, J. L. (2009): Whirling Disease in the United States. A summary of progress in research and management. Trout Unlimited and the Whirling Disease Foundation, Bozeman, Montana, USA. p. 61.

Yokoyama, H. and Urawa, S. (1997): Fluorescent labelling of actinospores for determining the portals of entry into fish. Dis. Aquat. Org. 30, 165-169.

This is an open-access article distributed under the terms of the Creative Commons Attribution 4.0 International License (https://creativecommons.org/licenses/by/4.0/), which permits unrestricted use, distribution, and reproduction in any medium, provided the original author and source are credited, a link to the CC License is provided, and changes - if any - are indicated. (SID_1) 